\title{
Directive 2002/98/EC of the European Parliament and of the Council of 27 January 2003
}

Setting standards of quality and safety for the collection, testing, processing, storage and distribution of human blood and blood components and amending Directive 2001/83/EC

\section{THE EUROPEAN PARLIAMENT AND THE COUNCIL OF THE EURO- PEAN UNION,}

Having regard to the Treaty establishing the European Community, and in particular Article 152(4)(a) thereof, Having regard to the proposal from the Commission (1), Having regard to the opinion of the Economic and Social Committee (2), Having regard to the opinion of the Committee of the Regions (3), Acting in accordance with the procedure laid down in Article 251 of the Treaty (4), in the light of the joint text approved by the Conciliation Committee on 4 November 2002, Whereas:

(1) The extent to which human blood is used therapeutically demands that the quality and safety of whole blood and blood components be ensured in order to prevent in particular the transmission of diseases.

(2) The availability of blood and blood components used for therapeutic purposes is dependent largely on Community citizens who are prepared to donate. In order to safeguard public health and to prevent the transmission of infectious diseases, all precautionary measures during their collection, processing, distribution and use need to be taken making appropriate use of scientific progress in the detection and inactivation and elimination of transfusion transmissible pathogenic agents.

(3) The quality, safety, and efficacy requirements of proprietary industriallyprepared medicinal products derived from human blood or plasma were ensured through Directive 2001/83/EC of the European Parliament and of the Council of 6 November 2001 on the Community code relating to medicinal products for human use (5). The specific exclusion of whole blood, plasma and blood cells of human origin from that Directive, however, has led to a situation whereby their quality and safety, in so far as they are intended for transfusion and not processed as such, are not subject to any binding Community legislation. It is essential, therefore, that whatever the intended purpose, Community provisions should ensure that blood and its components are of comparable quality and safety throughout the blood transfusion chain in all Member States, bearing in mind the freedom of movement of citizens within Community territory. The establishment of high standards of quality and safety, therefore, will help to reassure the public that human blood and blood components 
which are derived from donations in another Member State nonetheless meet the same requirements as those in their own country.

(4) In respect of blood or blood components as a starting material for the manufacture of proprietary medicinal products, Directive 2001/83/EC refers to measures to be taken by Member States to prevent the transmission of infectious diseases, comprising the application of the monographs of the European Pharmacopoeia and the recommendations of the Council of Europe and the World Health Organisation (WHO) as regards in particular the selection and testing of blood and plasma donors. Furthermore, Member States should take measures to promote Community self-sufficiency in human blood or blood components and to encourage voluntary unpaid donations of blood and blood components.

(5) In order to ensure that there is an equivalent level of safety and quality of blood components, whatever their intended purpose, technical requirements for the collection and testing of all blood and blood components including starting materials for medicinal products should be established by this Directive. Directive 2001/ 83/EC should be amended accordingly.

(6) The Commission's Communication of 21 December 1994 on Blood Safety and Self-sufficiency in the European Community identified the need for a blood strategy in order to reinforce confidence in the safety of the blood transfusion chain and promote Community self-sufficiency.

(7) In its Resolution of 2 June 1995, on blood safety and self-sufficiency in the Community (6), the Council invited the Commission to submit appropriate proposals in the framework of the development of a blood strategy. L 33/30 EN Official Journal of the European Union 8.2.2003

(8) In its Resolution of 12 November 1996 on a strategy towards blood safety and self-sufficiency in the European Community (1), the Council invited the Commission to submit proposals as a matter of urgency with a view to encouraging the development of a coordinated approach to the safety of blood and blood products.

(9) In its Resolutions of 14 September 1993 (2), 18 November 1993 (3), 14 July 1995 (4), and 17 April 1996 (5) on blood safety and self-sufficiency through voluntary unpaid donations in the European Community, the European Parliament stressed the importance of ensuring the highest level of blood safety and has reiterated its continued support for the objective of Community self-sufficiency.

(10) In elaborating the provisions of this Directive account has been taken of the opinion of the Scientific Committee for Medicinal Products and Medical Devices as well as international experience in this field.

(1) OJ C 154 E, 29.5.2001, p. 141 and OJ C 75 E, 26.3.2002, p. 104.

(2) OJ C 221, 7.8.2001, p. 106.

(3) OJ C 19, 22.1.2002, p. 6.

(4) Opinion of the European Parliament of 6 September 2001 (OJ C 72 E, 21.3.2002,p. 289), Council Common Position of 14 February 2002 (OJ C 113 E, 14.5.2002, p. 93) and Decision of the European Parliament of 12 June 2002 (not yet published in the Official Journal). Decision of the European Parliament of 18 December 2002 and Decision of the Council of 16 December 2002.

(5) OJ L 311, 28.11.2001, p. 67. (6) OJ C 164, 30.6.1995, p. 1. 
(11) The nature of autologous transfusion necessitates a specific consideration in respect of how and when to apply the different provisions of this Directive.

(12) Hospital blood banks are hospital units which perform a limited number of activities, storage, distribution, and compatibility tests. In order to ensure that the quality and safety of blood and blood components are preserved during the whole transfusion chain, while taking account of the specific nature and functions of hospital blood banks, only provisions relevant to these activities should apply to hospital blood banks.

(13) Member States should ensure that an appropriate mechanism for designating, authorising, accrediting or licensing exists to ensure that the activities of blood establishments are performed in accordance with the requirements of this Directive.

(14) Member States should organise inspection and control measures, to be carried out by officials representing the competent authority, to ensure the compliance of the blood establishment with the provisions of this Directive.

(15) Personnel directly involved in the collection, testing, processing, storage and distribution of blood and blood components need to be appropriately qualified and provided with timely and relevant training, without prejudice to existing Community legislation on the recognition of professional qualifications and on the protection of workers.

(16) Blood establishments should establish and maintain quality systems involving all activities that determine the quality policy objectives and responsibilities and implement them by such means as quality planning, quality control, quality assurance, and quality improvement within the quality system, taking into account the principles of good manufacturing practice as well as the EC conformity assessment system.

(17) An adequate system to ensure traceability of whole blood and blood components should be established. Traceability should be enforced through accurate donor, patient, and laboratory identification procedures, through record maintenance, and through an appropriate identification and labelling system. It is desirable that a system is developed in order to enable the unique and unmistakable identification of donations of blood and blood components in the Community. In the case of blood and blood components imported from third countries, it is important that an equivalent level of traceability be ensured by the blood establishments in the stages preceding importation into the Community. The same requirements of traceability which apply to blood and blood components collected in the Community should be ensured in the stages following importation.

(18) It is important to introduce a set of organised surveillance procedures to collect and evaluate information on the adverse or unexpected events or reactions resulting from the collection of blood or blood components in order to prevent similar or equivalent events or reactions from occurring thereby improving the security of transfusion by adequate measures. To this end a common system of notification of serious adverse events and reactions linked to the collection, processing, testing, storage, and distribution of blood and blood components should be established in Member States. 
(19) It is important that when abnormal findings are reported to the donor, relevant counselling is also provided.

(20) Modern blood-transfusion practice has been founded on the principles of voluntary donor services, anonymity of both donor and recipient, benevolence of the donor, and absence of profit on the part of the establishments involved in blood transfusion services.

(21) All necessary measures need to be taken in order to provide prospective donors of blood or blood components with assurances regarding the confidentiality of any health-related information provided to the authorised personnel, the results of the tests on their donations as well as any future traceability of their donation. 8.2.2003 EN Official Journal of the European Union L 33/31

(22) According to Article 152(5) of the Treaty, the provisions of this Directive cannot affect national provisions on the donations of blood. Article 152(4)(a) of the Treaty states that Member States cannot be prevented from maintaining or introducing more stringent protective measures as regards standards of quality and safety of blood and blood components.

(23) Voluntary and unpaid blood donations are a factor which can contribute to high safety standards for blood and blood components and therefore to the protection of human health. The efforts of the Council of Europe in this area should be supported and all necessary measures should be taken to encourage voluntary and unpaid donations through appropriate measures and initiatives and through ensuring that donors gain greater public recognition, thereby also increasing self-sufficiency. The definition of voluntary and unpaid donation of the Council of Europe should be taken into account.

(24) Blood and blood components used for therapeutic purposes or for use in medical devices should be obtained from individuals whose health status is such that no detrimental effects will ensue as a result of the donation and that any risk of transmission of infectious diseases is minimised; each and every blood donation should be tested in accordance with rules which provide assurances that all necessary measures have been taken to safeguard the health of individuals who are the recipients of blood and blood components.

(25) Directive 95/46/EC of the European Parliament and the Council of 24 October 1995 on the protection of individuals with regard to the processing of personal data and the free movement of such data (1) requires that data related to the health of an individual be subject to reinforced protection. However, it covers only personal data and not that rendered anonymous. This Directive should therefore introduce additional safeguards to prevent any unauthorised changes to donation registries, or processing records, or the unauthorised disclosure of information.

\footnotetext{
(1) OJ C 374, 11.12.1996, p. 1.

(2) OJ C $268,4.10 .1993$, p. 29.

(3) OJ C $329,6.12 .1993$, p. 268

(4) OJ C 249, 25.9.1995, p. 231

(5) OJ C 141, 13.5.1996, p. 131.
} 
(26) The Commission should be empowered to establish technical requirements and adopt any necessary changes thereto and to the Annexes in order to take into account scientific and technical progress.

(27) Setting of technical requirements and adaptation to progress should take into account the Council recommendation of 29 June 1998 on the suitability of blood and plasma donors and the screening of donated blood in the EC (2), relevant recommendations of the Council of Europe and the WHO as well as indications of relevant European institutions and organisations such as the monographs of the European Pharmacopoeia.

(28) It is necessary that the best possible scientific advice is available to the Community in relation to the safety of blood and blood components, in particular as regards adapting the provisions of this Directive to scientific and technical progress.

(29) Tests should be carried out in conformity with the latest scientific and technical procedures that reflect current best practice as defined by, and regularly reviewed and updated through, an appropriate expert consultation process. This review process should also take due account of scientific advances in the detection, inactivation and elimination of pathogens which can be transmitted via transfusion.

(30) The measures necessary for the implementation of this Directive should be adopted in accordance with Council Decision 1999/468/EC of 28 June 1999 laying down the procedures for the exercise of implementing powers conferred on the Commission (3).

(31) In order to increase the effective implementation of the provisions adopted under this Directive it is appropriate to provide for penalties to be applied by Member States.

(32) Since the objectives of this Directive, namely to contribute to general confidence both in the quality of donated blood and blood components and in the health protection of donors, to attain self-sufficiency at a Community level and to enhance confidence in the safety of the transfusion chain among the Member States, cannot be sufficiently achieved by the Member States and can therefore by reason of its scale and effects be better achieved at Community level, the Community may adopt measures, in accordance with the principle of subsidiarity as set out in Article 5 of the Treaty. In accordance with the principle of proportionality, as set out in that Article, this Directive does not go beyond what is necessary in order to achieve those objectives.

(33) Responsibility for the organisation of health services and the provision of medical care should remain the responsibility of each Member State,

HAVE ADOPTED THIS DIRECTIVE:

\section{CHAPTER I}

\section{GENERAL PROVISIONS}

\section{Article 1}


Objectives

This Directive lays down standards of quality and safety of human blood and of blood components, in order to ensure a high level of human health protection. L 33/32 EN Official Journal of the European Union 8.2.2003

\section{Article 2}

\section{Scope}

1. This Directive shall apply to the collection and testing of human blood and blood components, whatever their intended purpose, and to their processing, storage, and distribution when intended for transfusion.

2. Where blood and blood components are collected and tested for the sole purpose and exclusive use in autologous transfusion and are clearly identified as such, the requirements to be complied with in respect thereof shall be in accordance with those referred to in Article 29(g).

3. This Directive shall apply without prejudice to Directives 93/42/EEC (1), 95/46/EC or 98/79/EC (2).

4. This Directive does not apply to blood stem cells.

\section{Article 3}

\section{Definitions}

For the purposes of this Directive:

(a) 'blood' shall mean whole blood collected from a donor and processed either for transfusion or for further manufacturing

(b) 'blood component' shall mean a therapeutic constituent of blood (red cells, white cells, platelets, plasma) that can be prepared by various methods;

(c) 'blood product' shall mean any therapeutic product derived from human blood or plasma;

(d) 'autologous transfusion' shall mean transfusion in which the donor and the recipient are the same person and in which pre-deposited blood and blood components are used;

(e) 'blood establishment' shall mean any structure or body that is responsible for any aspect of the collection and testing of human blood or blood components, whatever their intended purpose, and their processing, storage, and distribution when intended for transfusion. This does not include hospital blood banks;

(f) 'hospital blood bank' shall mean a hospital unit which stores and distributes and may perform compatibility tests on blood and blood components exclusively for use within hospital facilities, including hospital based transfusion activities;

(g) 'serious adverse event' shall mean any untoward occurrence associated with the collection, testing, processing, storage and distribution, of blood and blood components that might lead to death or life-threatening, disabling or incapacitating conditions for patients or which results in, or prolongs, hospitalisation or morbidity; 
(h) 'serious adverse reaction' shall mean an unintended response in donor or in patient associated with the collection or transfusion of blood or blood components that is fatal, life-threatening, disabling, incapacitating, or which results in, or prolongs, hospitalisation or morbidity;

(i) 'blood component release' shall mean a process which enables a blood component to be released from a quarantine status by the use of systems and procedures to ensure that the finished product meets its release specification;

(j) 'deferral' shall mean suspension of the eligibility of an individual to donate blood or blood components such suspension being either permanent or temporary;

(k) 'distribution' shall mean the act of delivery of blood and blood components to other blood establishments, hospital blood banks and manufacturers of blood and plasma derived products. It does not include the issuing of blood or blood components for transfusion.

(1) 'haemovigilance' shall mean a set of organised surveillance procedures relating to serious adverse or unexpected events or reactions in donors or recipients, and the epidemiological follow-up of donors;

(m) 'inspection' shall mean formal and objective control according to adopted standards to assess compliance with this Directive and other relevant legislation and to identify problems.

\section{Article 4}

\section{Implementation}

1. Member States shall designate the competent authority or authorities responsible for implementing the requirements of this Directive.

2. This Directive shall not prevent a Member State from maintaining or introducing in its territory more stringent protective measures which comply with the provisions of the Treaty.

In particular, a Member State may introduce requirements for voluntary and unpaid donations, which include the prohibition or restriction of imports of blood and blood components, to ensure a high level of health protection and to achieve the objective set out in Article 20(1), provided that the conditions of the Treaty are met.

3. In carrying out the activities covered by this Directive the Commission may have recourse to technical and/or administrative assistance to the mutual benefit of the Commission and of the beneficiaries, relating to identification, preparation, management, monitoring, audit and control, as well as to support expenditure.

(1) Council Directive 93/42/EEC of 14 June 1993 concerning medical devices (OJ L 169, 12.7.1993, p. 1). Directive as last amended by Directive 2001/104/EC of the European Parliament and of the Council (OJ L 6, 10.1.2002, p. 50).

(2) Directive 98/79/EC of the European Parliament and of the Council of 27 October 1998 on in vitro diagnostic medical devices (OJ L 331, 7.12.1998, p. 1). 
8.2.2003 EN Official Journal of the European Union L 33/33

\section{CHAPTER II}

\section{OBLIGATIONS ON MEMBER STATES AUTHORITIES}

\section{Article 5}

\section{Designation, authorisation, accreditation or licensing of blood establishments}

1. Member States shall ensure that activities relating to the collection and testing of human blood and blood components, whatever their intended purpose, and to their preparation, storage, and distribution when intended for transfusion, are undertaken only by the blood establishments which have been designated, authorised, accredited or licensed by the competent authority for that purpose.

2. For the purpose of paragraph 1 , the blood establishment shall submit the information listed in Annex I to the competent authority.

3. The competent authority, having verified whether the blood establishment complies with the requirements set out in this Directive, shall indicate to the blood establishment which activities it may undertake and which conditions apply.

4. No substantial change in activities shall be undertaken by the blood establishment without prior written approval by the competent authority.

5. The competent authority may suspend or revoke the designation, authorisation, accreditation or licence of a blood establishment if inspection or control measures demonstrate that the blood establishment does not comply with the requirements of this Directive.

\section{Article 6}

\section{Hospital blood banks}

Articles 7, 10, 11(1), 12(1), 14, 15, 22 and 24 shall apply to hospital blood banks.

Article 7

\section{Provisions for existing establishments}

Member States may decide to maintain national provisions for nine months after the date laid down in Article 32 so as to enable blood establishments operating under their legislation to comply with the requirements of this Directive.

\section{Article 8}

\section{Inspection and control measures}

1. Member States shall ensure that the competent authority organise inspections and appropriate control measures in blood establishments to ensure that the requirements of this Directive are complied with.

2. Inspection and control measures shall be organised by the competent authority on a regular basis. The interval between two inspections and control measures shall not exceed two years. 
3. Such inspection and control measures shall be carried out by officials representing the competent authority who must be empowered to:

(a) inspect blood establishments as well as facilities of any third parties on its own territory entrusted by the holder of the designation, authorisation, accreditation or licence referred to in Article 5 with the task of carrying out evaluation and testing procedures pursuant to Article 18;

(b) take samples for examination and analysis;

(c) examine any documents relating to the object of the inspection, subject to the provisions in force in the Member States at the time of the entry into force of this Directive and which place restrictions on these powers with regard to the descriptions of the method of preparation.

4. The competent authority shall organise inspection and other control measures as appropriate in the event of any serious adverse event or reaction or suspicion thereof in accordance with Article 15.

\section{CHAPTER III}

\section{PROVISIONS FOR BLOOD ESTABLISHMENTS}

\section{Article 9}

\section{Responsible person}

1. Blood establishments shall designate a person (responsible person), responsible for:

- ensuring that every unit of blood or blood components has been collected and tested, whatever its intended purpose, and processed, stored, and distributed, when intended for transfusion, in compliance with the laws in force in the Member State,

- providing information to the competent authority in the designation, authorisation, accreditation or licensing procedures as required in Article 5,

- the implementation of the requirements of Articles 10,11, 12, 13, 14 and 15 in the blood establishment.

2. The responsible person shall fulfil the following minimum conditions of qualification:

(a) he/she shall possess a diploma, certificate or other evidence of formal qualifications in the field of medical or biological sciences awarded on completion of a university course of study or a course recognised as equivalent by the Member State concerned;

L 33/34 EN Official Journal of the European Union 8.2.2003 
(b) he/she shall have practical post-graduate experience in relevant areas for at least two years, in one or more establishments which are authorised to undertake activities related to collection and/or testing of human blood and blood components, or to their preparation, storage, and distribution.

3. The tasks specified in paragraph 1 may be delegated to other persons who shall be qualified by training and experience to perform such tasks.

4. Blood establishments shall notify the competent authority of the name of the responsible person referred to in paragraph 1 and other persons referred to in paragraph 3 together with information on the specific tasks for which they are responsible.

5. Where the responsible person or such other persons referred to in paragraph 3 are permanently or temporarily replaced, the blood establishment shall provide immediately the name of the new responsible person and his or her date of commencement to the competent authority.

Article 10

Personnel

Personnel directly involved in collection, testing, processing, storage, and distribution of human blood and blood components shall be qualified to perform those tasks and be provided with timely, relevant and regularly updated training.

\section{CHAPTER IV}

\section{QUALITY MANAGEMENT}

\section{Article 11}

\section{Quality system for blood establishments}

1. Member States shall take all necessary measures to ensure that each blood establishment establishes and maintains a quality system for blood establishments based on the principles of good practice.

2. The Commission shall establish the Community standards and specifications referred to in Article 29(h) for the activities relating to a quality system to be carried out by a blood establishment.

Article 12

\section{Documentation}

1. Member States shall take all necessary measures in order to ensure that blood establishments maintain documentation on operational procedures, guidelines, training and reference manuals, and reporting forms.

2. Member States shall take all necessary measures in order to ensure that access is provided to these documents for officials entrusted with inspection and control measures referred to in Article 8. 


\section{Article 13}

\section{Record keeping}

1. Member States shall take all necessary measures to ensure that blood establishments maintain records of the information required in Annexes II and IV and under Article 29(b), (c) and (d). The records shall be kept for a minimum of 15 years.

2. The competent authority shall keep records of the data received from the blood establishments according to Articles 5, 7, 8, 9 and 15.

\section{CHAPTER V}

\section{HAEMOVIGILANCE}

\section{Article 14}

\section{Traceability}

1. Member States shall take all necessary measures in order to ensure that blood and blood components collected, tested, processed, stored, released and/or distributed on their territory can be traced from donor to recipient and vice versa. To this end, Member States shall ensure that blood establishments implement a system for identification of each single blood donation and each single blood unit and components thereof enabling full traceability to the donor as well as to the transfusion and the recipient thereof. The system must unmistakably identify each unique donation and type of blood component. This system shall be established in accordance with the requirements referred to in Article 29(a). With regard to blood and blood components imported from third countries, Member States shall ensure that the donor identification system to be implemented by blood establishments permits an equivalent level of traceability.

2. Member States shall take all necessary measures in order to ensure that the system used for the labelling of blood and blood components collected, tested, processed, stored, released and/or distributed on their territory complies with the identification system referred to in paragraph 1 and the labelling requirements listed in Annex III.

3. Data needed for full traceability in accordance with this Article shall be kept for at least 30 years.

\section{Article 15}

\section{Notification of serious adverse events and reactions}

1. Member States shall ensure that:

- any serious adverse events (accidents and errors) related to the collection, testing, processing, storage and distribution of blood and blood components 
which may have an influence on their quality and safety, as well as any serious adverse reactions observed during or after transfusion which may be attributed to the quality and the safety of blood and blood components are notified to the competent authority, 8.2.2003 EN Official Journal of the European Union L 33/35

- blood establishments have in place a procedure accurately, efficiently and verifiably to withdraw from distribution blood or blood components associated with the notification referred to above.

2. These serious adverse events and reactions shall be notified in accordance with the procedure and notification format referred to in Article 29(i).

\section{CHAPTER VI}

\section{PROVISIONS FOR THE QUALITY AND SAFETY OF BLOOD}

\section{AND BLOOD COMPONENTS}

\section{Article 16}

\section{Provision of information to prospective donors}

Member States shall ensure that all prospective donors of blood or blood components in the Community are provided with information referred to in Article 29(b).

\section{Article 17}

\section{Information required from donors}

Member States shall take all necessary measures to ensure that, upon agreement of a willingness to commence the donation of blood or blood components, all donors in the Community provide the information referred to in Article 29(c) to the blood establishment.

\section{Article 18}

\section{Eligibility of donors}

1. Blood establishments shall ensure that there are evaluation procedures in place for all donors of blood and blood components and that the criteria for donation referred to in Article 29(d) are met.

2. The results of the donor evaluation and testing procedures shall be documented and any relevant abnormal findings shall be reported to the donor.

\section{Article 19}

\section{Examination of donors}

An examination of the donor, including an interview, shall be carried out before any donation of blood or blood components. A qualified health professional shall be responsible, in particular, for giving to and gathering from donors the information which is necessary to assess their eligibility to donate and shall, on the basis thereof, assess the eligibility of donors. 


\section{Article 20}

\section{Voluntary and unpaid blood donation}

1. Member States shall take the necessary measures to encourage voluntary and unpaid blood donations with a view to ensuring that blood and blood components are in so far as possible provided from such donations.

2. Member States shall submit reports to the Commission on these measures two years after the entry into force of this Directive, and thereafter every three years. On the basis of these reports the Commission shall inform the European Parliament and the Council of any necessary further measure it intends to take at Community level.

\section{Article 21}

\section{Testing of donations}

Blood establishments shall ensure that each donation of blood and blood components is tested in conformity with requirements listed in Annex IV. Member States shall ensure that blood and blood components imported into the Community are tested in conformity with requirements listed in Annex IV.

\section{Article 22}

\section{Storage, transport and distribution conditions}

Blood establishments shall ensure that the storage, transport and distribution conditions of blood and blood components comply with the requirements referred to in Article 29(e).

\section{Article 23}

\section{Quality and safety requirements for blood and blood components}

Blood establishments shall ensure that quality and safety requirements for blood and blood components meet the high standards in compliance with the requirements referred to in Article 29(f).

\section{CHAPTER VII}

\section{DATA PROTECTION}

\section{Article 24}

\section{Data protection and confidentiality}

Member States shall take all necessary measures to ensure that all data, including genetic information, collated within the scope of this Directive to which third parties have access have been rendered anonymous so that the donor is no longer identifiable. For that purpose, they shall ensure:

(a) that data security measures are in place as well as safeguards against unauthorised data additions, deletions or modifications to donor files or deferral records, and transfer of information; 
(b) that procedures are in place to resolve data discrepancies;

(c) that no unauthorised disclosure of such information occurs, whilst guaranteeing the traceability of donations. L 33/36 EN Official Journal of the European Union 8.2.2003

\section{CHAPTER VIII}

\section{EXCHANGE OF INFORMATION, REPORTS AND PENALTIES}

\section{Article 25}

\section{Information exchange}

The Commission shall hold regular meetings with the competent authorities designated by the Member States, delegations of experts from blood establishments and other relevant parties to exchange information on the experience acquired with regard to the implementation of this Directive.

\section{Article 26}

\section{Reports}

1. Member States shall send to the Commission, commencing on 31 December 2003 and every three years thereafter, a report on the activities undertaken in relation to the provisions of this Directive, including an account of the measures taken in relation to inspection and control.

2. The Commission shall transmit to the European Parliament, the Council, the Economic and Social Committee and the Committee of the Regions, the reports submitted by the Member States on the experience gained in implementing this Directive.

3. The Commission shall transmit to the European Parliament, the Council, the Economic and Social Committee and the Committee of the Regions, commencing on 1 July 2004 and every three years thereafter, a report on the implementation of the requirements in this Directive, and in particular those relating to inspection and control.

\section{Article 27}

\section{Penalties}

Member States shall lay down the rules on penalties applicable to infringements of the national provisions adopted pursuant to this Directive and shall take all measures necessary to ensure that they are implemented. The penalties provided for must be effective, proportionate, and dissuasive. Member States shall notify those provisions to the Commission by the date specified in Article 32 at the latest and shall notify it without delay of any subsequent amendments affecting them. 


\section{CHAPTER IX}

\section{COMMITTEES}

Article 28

\section{Regulatory procedure}

1. The Commission shall be assisted by a Committee.

2. Where reference is made to this paragraph, Articles 5 and 7 of Decision 1999/468/EC shall apply, having regard to the provisions of Article 8 thereof. The period referred to in Article 5(6) of Decision 1999/468/EC shall be set at three months.

3. The Committee shall adopt its rules of procedure.

\section{Article 29}

Technical requirementsand their adaptation to technical and scientific progress

The adaptation of the technical requirements set out in Annexes I to IV to technical and scientific progress shall be decided in accordance with the procedure referred to in Article 28(2). The following technical requirements and their adaptation to technical and scientific progress shall be decided in accordance with the procedure referred to in Article 28(2):

(a) traceability requirements;

(b) information to be provided to donors;

(c) information to be obtained from donors including the identification, health history, and the signature of the donor;

(d) requirements concerning the suitability of blood and plasma donors and the screening of donated blood including

- permanent deferral criteria and possible exemption thereto

- temporary deferral criteria;

(e) storage, transport and distribution requirements;

(f) quality and safety requirements for blood and blood components;

(g) requirements applicable to autologous transfusions;

(h) Community standards and specifications relating to a quality system for blood establishments;

(i) Community procedure for notifying serious adverse reactions and events and notification format.

Article 30

\section{Consultation of scientific committee(s)}

The Commission may consult the relevant scientific committee(s) when establishing the technical requirements referred to in Article 29 and when adapting the 
technical requirements set out in Annexes I to IV to scientific and technical progress, in particular with a view to ensuring an equivalent level of quality and safety of blood and blood components used for transfusion and blood and blood components used as a starting material for the manufacture of medicinal products. 8.2.2003 EN Official Journal of the European Union L 33/37

\section{CHAPTER X}

\section{FINAL PROVISIONS}

Article 31

\section{Amendment of Directive 2001/83/EC}

Article 109 of Directive 2001/83/EC shall be replaced by the following:

'Article 109

For the collection and testing of human blood and human plasma, Directive 2002/98/EC of the European Parliament and of the Council of 27 January 2003 setting standards of quality and safety for the collection, testing, processing, storage and distribution of human blood and blood components and amending Directive 2001/83/EC (*) shall apply.

(*) OJ L 33, 8.2.2003, p. 30.'

\section{Article 32}

\section{Transposition}

1. Member States shall bring into force the laws, regulations and administrative provisions necessary to comply with this Directive not later than 8 February 2005. They shall forthwith inform the Commission thereof. When Member States adopt those provisions, they shall contain a reference to this Directive or shall be accompanied by such reference on the occasion of their official publication. Member States shall determine how such reference is to be made.

2. Member States shall communicate to the Commission the texts of the provisions of national law that they have already adopted or which they adopt in the field governed by this Directive.

Article 33

\section{Entry into force}

This Directive shall enter into force on the day of its publication in the Official Journal of the European Union.

\section{Article 34}

\section{Addressees}

This Directive is addressed to the Member States. Done at Brussels, 27 January 2003.

For the European Parliament

The President 
P. COX

For the Council

The President

G. DRYS

L 33/38 EN Official Journal of the European Union 8.2.2003

ANNEX I

INFORMATION TO BE PROVIDED BY BLOOD ESTABLISHMENT TO THE COMPETENT AUTHORITY FOR

THE PURPOSES OF DESIGNATION, AUTHORISATION, ACCREDITATION OR LICENSING IN ACCORDANCE

\section{WITH ARTICLE 5(2)}

Par t A: General information:

- identification of the blood establishment

- name, qualification and contact details of responsible persons

- a list of hospital blood banks which it supplies. Par t B: A description of the quality system, to include:

- documentation, such as an organisation chart, including responsibilities of responsible persons and reporting relationships

- documentation such as site master file or quality manual describing the quality system in accordance with Article 11(1)

- number and qualifications of personnel

- hygiene provisions

- premises and equipment

- list of standard operating procedures for recruitment, retention and assessment of donors, for processing and testing, distribution and recall of blood and blood components and for the reporting and recording of serious adverse reactions and events. 8.2.2003 EN Official Journal of the European Union L 33/39

\section{ANNEX II}

REPORT OF THE BLOOD ESTABLISHMENT'S PRECEDING YEAR'S

\section{ACTIVITY}

This annual report will include:

- total number of donors who give blood and blood components

- total number of donations

- an updated list of the hospital blood banks which it supplies

- total number of whole donations not used

- number of each component produced and distributed

- incidence and prevalence of transfusion transmissible infectious markers in donors of blood and blood components

- number of product recalls

- number of serious adverse events and reactions reported. 


\section{ANNEX III}

\section{LABELLING REQUIREMENTS}

The label on the component must contain the following information:

- the official name of the component

- the volume or weight or number of cells in the component (as appropriate)

- the unique numeric or alphanumeric donation identification

- the name of producing blood establishment

- the ABO Group (not required for plasma intended only for fractionation)

- the Rh D Group, either Rh D positive or Rh D negative (not required for plasma intended only for fractionation)

- the date or time of expiry (as appropriate)

- the temperature of storage

- the name, composition and volume of anticoagulant and/or additive solution (if any).

L 33/40 EN Official Journal of the European Union 8.2.2003

\section{ANNEX IV}

BASIC TESTING REQUIREMENTS FOR WHOLE BLOOD AND PLASMA DONATIONS

The following tests must be performed for whole blood and apheresis donations, including autologous predeposit donations:

- ABO Group (not required for plasma intended only for fractionation)

- Rh D Group (not required for plasma intended only for fractionation)

- testing for the following infections in the donors:

- Hepatitis B (HBs-Ag)

- Hepatitis C (Anti-HCV)

- HIV 1/2 (Anti-HIV 1/2)

Additional tests may be required for specific components or donors or epidemiological situations. 